\title{
Urszula Zagóra-Jonszta*
}

Uniwersytet Ekonomiczny w Katowicach

Wydział Ekonomii

\section{PAŃSTWO SOCJALISTYCZNE W POGLĄDACH HAYEKA I SCHUMPETERA}

\section{STRESZCZENIE}

W artykule przedstawiono stanowisko dwóch austriackich ekonomistów: Friedricha Augusta von Hayeka i Josepha Aloisa Schumpetera wobec funkcjonowania państwa socjalistycznego. Obaj byli zwolennikami gospodarki kapitalistycznej, lecz Hayek zdecydowanie negował możliwość racjonalności państwa socjalistycznego, natomiast Schumpeter, dostrzegając wady kapitalizmu, widział możliwość funkcjonowania gospodarki socjalistycznej stosującej rachunek ekonomiczny.

Słowa kluczowe: Hayek, Schumpeter, socjalizm

\section{Wprowadzenie}

Debata wokół możliwości funkcjonowania gospodarki socjalistycznej rozgorzała pod koniec XIX wieku i trwała przez długie lata, niezależnie od faktu, że w międzyczasie idea „sprawiedliwego państwa” została wcielona w życie.

W artykule przedstawiono stanowisko wobec założeń socjalizmu dwóch wybitnych przedstawicieli szkoły austriackiej: Friedricha Augusta von Hayeka

\footnotetext{
*Adres e-mail: urszula.zagora-jonszta@ue.katowice.pl
} 
(1899-1992) oraz Josepha Aloisa Schumpetera (1883-1950). Pierwszy był zdeklarowanym przeciwnikiem socjalistycznych eksperymentów i nie wierzył w sprawne funkcjonowanie państwa socjalistycznego, drugi, mimo że daleki od akceptacji tego ustroju, widział możliwość jego rozwoju. W tekście zwrócono uwagę na różnice stanowisk obu Austriaków. Starano się też dociec, na ile tezy zawarte w ich pracach okazały się prawdziwe.

\section{Stosunek Hayeka do socjalizmu}

Friedrich August von Hayek nie był początkowo krytykiem aktywnej roli państwa. Sympatyzował z nurtem fabiańskim, jednak uległ urokowi i osobowości Ludwiga von Misesa ${ }^{1}$, stając się godnym kontynuatorem jego myśli.

Twierdził, że nie ma żadnego historycznego prawa, które by powodowało nieuniknione przejście z kapitalizmu do socjalizmu (Hayek, 1976). Uważał, że od początku socjalizm był mylnie interpretowany, a częste niepowodzenia na gruncie polityki gospodarczej państw próbujących budować ten ustrój stanowią wystarczający argument przeciwko błędnemu założeniu, że człowiek potrafi kształtować otaczający go świat zgodnie ze swoimi życzeniami. Dlatego podkreślał, że socjalistyczne eksperymenty muszą być jak najszybciej odrzucone (Hayek, 1988). Socjalizm opierał się na kolektywizmie, sprzecznym z ideologią Zachodu. Ubolewał, że wielu ludzi wykształconych dało się zwieść tej idei, mimo że w praktyce okazała się błędna (Hayek, 2006, s. 378-380). Negował możliwość zastąpienia rynku planem, który wymagałby zebrania ogromnej ilości informacji oraz ich przetworzenia w celu podjęcia optymalnych decyzji. Jego zdaniem, było to niewykonalne ze względów technicznych (Hayek, 1940). Nawet później, w czasach komputeryzacji, nie zmienił zdania. Ani skomplikowana kalkulacja kosztów, ani wyznaczanie cen w gospodarce planowej nie mogło się równać ze swobodną grą rynkową, która w sposób automatyczny załatwiała ten problem, nie angażując sztabu specjalistów, dysponujących niepełną informacją i rozproszoną wiedzą. Odrzucał centralne planowanie uważając, że jest nieefektywne i zagraża wolności jednostki.

Hayek twierdził również, że kolektywizm i centralne planowanie niszczą demokrację, która z kolei jest gwarantem pokoju wewnętrznego i wolności. Planowanie pozbawia obywateli samodzielnego rozwiązywania problemów, niszczy inicjatywę

\footnotetext{
Z uwagi na ograniczoną objętość artykułu pominięto jego bogaty wkład do krytyki socjalizmu.
} 
jednostek i pozbawia możliwości wyboru (Hayek, 1996, s. 100-101). Swoją znaną pracę Droga do zniewolenia wydaną w 1944 roku dedykował socjalistom i socjaldemokratom, przestrzegając ich przed zgubnymi skutkami ograniczania wolności gospodarczej przez państwo socjalistyczne. „Nie będzie żadną przesadą stwierdzenie - pisał - że gdybyśmy w celu osiągnięcia rozwoju naszego systemu przemysłowego musieli zdać się na centralne planowanie, nigdy nie osiągnąłby on tego stopnia zróżnicowania i elastyczności, jaki posiada" (1996, s. 57).

Wybór między gospodarką rynkową a socjalistyczną polegał na wyborze między systemem, w którym wola kilku osób decydowała o tym, kto, co i ile ma otrzymać, a systemem, który preferował zdolności i przedsiębiorczość jednostek, uwzględniając również obiektywne okoliczności (Hayek, 1996, s. 109).

W miarę upływu czasu stanowisko Hayeka wobec gospodarki socjalistycznej stawało się coraz bardziej agresywne. Już w wykładzie z 1976 roku uznał, że zbyt łagodnie krytykował dotąd ten system i że dawno już należało mocno artykułować, iż intelektualne podstawy socjalizmu są fałszywe (Hayek, 1976). Napastliwy ton wobec państwa socjalistycznego widać jeszcze wyraźniej w artykule z 1982 roku, w którym Hayek rozprawiał się ze stanowiskiem Oskara Langego, dotyczącym możliwości stosowania rachunku ekonomicznego w socjalizmie (Hayek, 1982).Według niego gospodarka sama w sobie jest zbyt skomplikowana, aby można ją było opisać nawet za pomocą dużej ilości danych, tworzących układ równań z mnóstwem niewiadomych. Najbardziej rozbudowane metody matematyczne, stanowiące narzędzie pomiaru gospodarki, nie mogły zastąpić rynku. Głęboko wierzył w pozytywne możliwości mechanizmu rynkowego umożliwiającego efektywny rozwój społeczeństw, dlatego krytykował arbitralność państwa i podporządkowanie ludzkiego umysłu odgórnie ustalonej hierarchii wartości.

Idea państwa socjalistycznego zakładała społeczną własność środków produkcji i ich wykorzystanie w celu jak najlepszego zaspokojenia potrzeb całego społeczeństwa. Jednak po latach intelektualnej atrakcyjności socjalizm, zdaniem Hayeka, nie tylko utracił powab, ale wręcz się skompromitował. Powodem tego były: 1) rosnące przekonanie, że państwo socjalistyczne jest mniej efektywne niż gospodarka kapitalistyczna; 2) brak realizacji zasady sprawiedliwości społecznej i coraz bardziej sztywna hierarchia społeczna; 3) pojawienie się nowego despotyzmu niszczącego wolność jednostki, miast obiecanej swobody (Hayek, 2006, s. 252-253). Sprawiedliwość społeczną uznał za slogan nieracjonalny i demoralizujący, ponieważ 
nie może się ona odnosić do całego społeczeństwa lub do rynku, tylko do jednostki. Chęć wdrożenia jej w życie doprowadzi do erozji wolności osobistych i totalitaryzmu. Równość materialna, która mieści się w pojęciu sprawiedliwości społecznej, wymaga redystrybucji dochodów z rąk jednych obywateli do drugich, co jest sprzeczne z założeniami państwa prawa i ideą sprawiedliwości (Hayek, 1977). Hayek przestrzegał przed nadal aktualnym niebezpieczeństwem socjalizmu, które współcześnie przybierało postać państwa opiekuńczego. Nawet niechcący może ono niszczyć mechanizm rynkowy i podporządkowywać decyzje gospodarcze centralnej kontroli, dowodził w swojej sztandarowej pracy Konstytucja wolności wydanej po raz pierwszy w 1960 roku (Hayek, 2006, s. 254). Zagrożenie ze strony welfare state jest poważne, nie ma bowiem jasno wyznaczonych granic działania i istnieje obawa zagarnięcia przez nie tych dziedzin, które ograniczają wolność. Rozszerzanie sfery usług przez państwo opiekuńcze opiera się często na państwowych uprawnieniach przymusu i monopolu państwa w pewnych dziedzinach. Trudno jednak z tym walczyć, gdyż państwo opiekuńcze zawiera w sobie konglomerat wielu różnorodnych elementów, z których tylko część zagraża wolności. Niemniej często tak się dzieje, że gdy jakiś cel rządu uznaje się powszechnie za uzasadniony, państwo opiekuńcze stara się go realizować w sposób arbitralny, sprzeczny z wolnością. Staje się wówczas „państwem «domowym» (household state), w którym paternalistyczna władza kontroluje większą część dochodu wspólnoty i rozdziela go między jednostki w formie i ilościach, na jakie według niej zasługują" (Hayek, 2006, s. 258).

Rozważania Hayeka nad gospodarką kolektywistyczną dobrze pointują opinie dwojga największych znawców jego teorii. Janina Godłów-Legiędź (1992, s. 240241) pisze:

Nikt tak dobitnie jak Hayek nie podkreślał, że rynek i konkurencja są źródłem informacji, bez której racjonalne gospodarowanie jest niemożliwe. I nikt chyba nie poświęcił tyle uwagi wszechstronnemu dowodzeniu (...), że gospodarka rynkowa jest fundamentem cywilizacji, a centralne planowanie niszczy twórcze siły społeczeństwa tkwiące w żywiołowości, konkurencji i inicjatywie jednostki.

Wtóruje jej Krzysztof Kostro (2001, s. 13), stwierdzając:

Ideologia i teoria socjalizmu były kluczowym czynnikiem determinującym rozwój jego teorii ekonomicznych (...). Tę niezwykłą przemianę spowodowała krytyka socjalizmu, zapoczątkowana debatą nad rachunkiem ekonomicznym w so- 
cjalizmie. (...) Antysocjalizm Hayeka był buntem przeciwko traktowaniu rozumu jako wszechmocnego narzędzia, zdolnego do zaprojektowania porządku społeczno-ekonomicznego (...).

Kostro uznał wręcz, że rozwój teorii ekonomicznych Hayeka dokonał się pod wpływem zaangażowania w krytykę państwa socjalistycznego. Zmusiło go to do sformułowania własnej teorii kosztów i ceny oraz do rozszerzenia badań naukowych o elementy etyczne, filozoficzne i instytucjonalno-prawne, dzięki czemu jego teoria stała się bogatsza.

\section{Joseph Alois Schumpeter o gospodarce socjalistycznej}

Drugi z Austriaków, który podobnie jak Hayek spędził wiele lat poza granicami kraju (w Stanach Zjednoczonych), również rozważaniom nad państwem socjalistycznym poświęcił sporo uwagi. Będąc zwolennikiem kapitalizmu i jednocześnie przewidując jego upadek, stał się prawdziwym obrazoburcą (Gintis, 1990, s. 27). Najbardziej znana praca Kapitalizm, socjalizm, demokracja, wydana w 1942 roku, jest, jak sam pisał, zwieńczeniem jego 40-letnich badań nad zawartymi w dziele problemami. Z punktu widzenia tematu artykułu interesująca jest trzecia część rozprawy, poświęcona mankamentom gospodarki socjalistycznej. Główna teza pracy była dość szokująca. Schumpeter starał się wykazać, że „socjalistyczna forma społeczeństwa wyłoni się w sposób nieunikniony z równie nieuchronnego rozkładu społeczeństwa kapitalistycznego" (1995, s. XXIII). Dziś wiadomo, że ta przepowiednia się nie spełniła, choć Schumpeter tezę taką po raz pierwszy sformułował już w artykule z 1918 roku Kryzys państwa podatków. Nie znaczy to, że wizja zastąpienia kapitalizmu gospodarką centralnie planowaną sprawiała mu przyjemność. Był przecież zdeklarowanym zwolennikiem systemu opartego na prywatnej własności i sprawnie działającym mechanizmie rynkowym. Pewna niespójność samej pracy i niedomówienia w niej zawarte spowodowały ${ }^{2}$, że była jednak różnie odczytywana. Zwolennicy gospodarki kapitalistycznej postrzegali ją jako obronę wartości rynkowych i demokracji, zwolennicy socjalizmu widzieli w niej przyznanie wyższości państwu socjalistycznemu i nieuchronność transformacji kapitalizmu w socjalizm. Debata

2 Schumpeter traktował ją jako zbiór esejów i w takim zamyśle wydał. Nie przypuszczał, że będzie bardziej znana i zrobi większą karierę niż dzieło jego życia Bussines Cycles. 
wokół właściwego rozumienia zawartych w niej myśli trwa do dziś. Konstrukcja pracy jest nietypowa. Po głębokiej analizie teorii Karola Marksa, wykazującej jej zalety i wady, zawartej w pierwszej części dzieła, Schumpeter przeszedł do kolejnego ważnego zagadnienia dotyczącego dalszych losów państwa kapitalistycznego. Drugą część zatytułował Czy kapitalizm może przetrwać? I na tak postawione pytanie od razu odpowiedział: „Nie. Nie sądzę, by mógł” (Schumpeter, 1995, s. 75). Opinia ta nie wynikała wszak z akceptacji socjalizmu, ale, jak sam przyznawał, z chłodnej kalkulacji: „Można nienawidzić socjalizmu albo przynajmniej podchodzić do niego z chłodnym krytycyzmem, a jednak przewidywać jego nadejście” (1995, s. 76). Mimo że w żadnym razie nie można uznawać go za zwolennika państwa socjalistycznego, jednak w przeciwieństwie do Hayeka uważał, że może ono funkcjonować w miarę sprawnie i przewidywał jego ekspansję. Uczestniczył w słynnej debacie na temat racjonalności systemu nakazowego, polemizując z Misesem i Hayekiem. Pomijał przy tym kwestię moralności własności państwowej, wykonalności państwowego planowania i rolę rynku kontra planu (Gintis, 1990, s. 28). Hayek skomentował to z przekąsem, że profesor Schumpeter jest oryginalnym autorem mitu, iż Barone i Pareto rozwiązali problem socjalizmu. Tymczasem oni tylko określili warunki, które musiałaby spełniać racjonalna alokacja zasobów, i wykazali, że są właściwie takie same jak warunki równowagi na konkurencyjnym rynku (Hayek, 1945).

Kapitalizm na razie nie wykazywał oznak degeneracji. Schumpeter twierdził, że jeszcze przez co najmniej pół wieku zapewni wzrost dobrobytu całego społeczeństwa. Co więc miało być powodem jego upadku? Zdaniem Schumpetera, siła ekonomiczna kapitalizmu rodziła tendencje do osłabienia ram instytucjonalnych. Posiłkując się terminologią marksistowską, uznał, że niebezpieczeństwo upadku tkwiło w nadbudowie. Rodzący się kapitalizm przyciągał jednostki silne i inteligentne, którym stworzył warunki do kreatywnego działania. W ten sposób powstała klasa kapitalistów. Ciągły rozwój techniki i wzrost produkcji spowoduje jednak nasycenie gospodarki. W sposób naturalny zniknie burżuazja, rentierzy, spadną zyski i procenty, a gospodarka niepostrzeżenie przeobrazi się w socjalistyczną. Zniknie funkcja przedsiębiorcy, który swą kreatywnością pchał do przodu rozwój ekonomiczny. Nie będzie potrzeby korzystać z jego ponadprzeciętnych zdolności, innowacji coraz częściej dokonuje bowiem zespół fachowców różnych branż zatrudnianych przez wielkie koncerny (McCaffrey, 2009). 
$\mathrm{Z}$ drugiej strony degeneracja kapitalizmu wynikała z porzucenia trwającej dotąd symbiozy przedsiębiorców z arystokracją. Mariaże między klasą nowobogackich prężnych kapitalistów a arystokracją zapewniały powodzenie, ponieważ ta pierwsza miała zmysł ekonomiczny, ta druga zaś prestiż i zdolności panowania nad innymi, nawyk przewodzenia i wymuszania posłuchu.

Kapitalizm zniósł instytucje feudalne, ale prąc do przodu, znosi też strukturę instytucjonalną własnego ustroju. Wielkie koncerny wypierają małą i średnią własność. Na ich czele stoją dyrektorzy, którzy są pracownikami administracyjnymi, własność jest rozproszona między akcjonariuszy, znika dawna kapitalistyczna prywatna własność. Proces oddzielenia kapitału-własności od kapitału-funkcji spowodował zanik tradycyjnego kapitalizmu i powolną transformację w kierunku socjalizmu. Jak zauważa Adam Glapiński, Schumpeter w tych poglądach antycypował tezy kapitalizmu menedżerskiego, rewolucji menedżerskiej i teorii praw własności (Glapiński, 2004, s. 255).

Kolejnym argumentem przemawiającym za destrukcją kapitalizmu była, zdaniem Schumpetera, wroga postawa wobec tego ustroju samego społeczeństwa. Przeciętny obywatel, pod wpływem związków zawodowych, kojarzył go z dążeniem do egoistycznego zysku i niegospodarnością. Ukrócenie działalności związków jest niemożliwe, gdyż odebrano by to jako zamach na demokrację.

Schumpeter uważał, że kolejna cecha powodująca demontaż kapitalizmu tkwiła wewnątrz samej burżuazji i był nią zanik wzorca mieszczańskiej rodziny, spadek znaczenia życia rodzinnego i spadek dzietności rodzin. Współczesny homo oeconomicus patrzył pod kątem własnych korzyści, a dzieci oznaczały koszty, zysk kalkulował zatem w perspektywie swojego pokolenia. Zanikał motyw oszczędzania a konto przyszłych pokoleń. Wszystkie wymienione wyżej przyczyny upadku kapitalizmu dawały możliwość powstania w jego miejsce gospodarki socjalistycznej.

Trzecią część pracy, zatytułowaną Czy socjalizm może funkcjonować?, poświęcił więc temu systemowi, a na tak postawione pytanie odpowiedział: „Oczywiście, że może” (Schumpeter, 1995, s. 207). W jego ujęciu socjalizm był formacją scentralizowaną, opartą na społecznej własności i odgórnym rozdzielnictwie leżącym w gestii władzy centralnej. Zaznaczał jednak, że takie państwo jeszcze nie istnieje (nie jest nim Rosja), jest teoretycznym modelem. Uważał taki socjalizm za logiczny i przyłączył się do chóru ekonomistów dyskutujących nad racjonalnością gospodarki socjalistycznej, popierając tezy Langego. Uznał, że w każdym systemie logika produkcji, podziału, 
konsumpcji, oszczędności, inwestycji jest taka sama, zgodna z powszechną logiką wyboru i nie ma zabarwienia politycznego. Wbrew obawom Hayeka twierdził, że nowoczesna biurokracja poradzi sobie ze skomplikowaną gospodarką i potrafi podejmować racjonalne decyzje. Zaprzeczał również dość powszechnej tezie o egoizmie ludzkiej natury uniemożliwiającym budowanie socjalizmu.

Porównując kapitalizm monopolistyczny z teoretycznym modelem socjalizmu, wskazywał na zalety tego drugiego w postaci:

- większego zadowolenia zdeklarowanych socjalistów z faktu, że żyją w takim państwie;

- większej równości w dochodach, co wiąże się z zadowoleniem większości;

- większej efektywności w związku z ograniczeniem niepewności i racjonalnymi decyzjami, które zmniejszają koszty;

- złagodzenia wahań koniunktury dzięki centralnemu planowaniu;

- skutecznego rozwiązania problemu bezrobocia;

- mniejszego marnotrawstwa na skutek planowego i przemyślanego działania;

- zaniku antagonizmów między sferą publiczną a prywatną i braku konfliktów związanych z pobieraniem podatków, ponieważ uważał, że znikną wraz z państwem burżuazyjnym.

Zaznaczając, że ocena socjalizmu opiera się na czysto teoretycznej konstrukcji i że w praktyce może nie zostać zrealizowana, stwierdzał, iż ,projekt socjalistyczny jest sporządzony na wyższym poziomie racjonalności” (Schumpeter, 1995, s. 245). Kwestią otwartą pozostawał sposób przejścia do socjalizmu, które mogło się dokonać w formie socjalizacji dojrzałej lub przedwczesnej. Pierwsza forma była przemyślana, stopniowa i rokowała pozytywnie, odrzucając rewolucyjną drogę socjalizacji przedwczesnej.

Postawił również problem związku socjalizmu z demokracją, uznając, że teoretycznie mogą one współistnieć, choć niebezpieczeństwem będzie pokusa wykorzystania ogromnej władzy, jaką będą mieli ludzie zarządzający gospodarką (Schumpeter, 1995, s. 377).

Choć wielu ekonomistów do dziś uważa, że Schumpeter sympatyzował z ideologią socjalistyczną, on sam pod koniec życia wyraźnie oświadczył: „Nie jestem obrońcą socjalizmu. Nie mam również zamiaru podejmować problemu, czy jest on pożądany, czy niepożądany, cokolwiek by to miało znaczyć" (1995, s. 380). Po prostu logicznie rozumując, doszedł do wniosku, że socjalizm będzie kolejnym eta- 
pem rozwoju ludzkości. Należy również pamiętać, że pozytywna ocena państwa socjalistycznego dotyczyła teoretycznego modelu, do którego realizacji w praktyce Schumpeter sam miał wątpliwości.

\section{Podsumowanie}

O ile stanowisko Hayeka wobec gospodarki socjalistycznej było jednoznacznie negatywne, mimo, a może właśnie dlatego że mógł obserwować funkcjonowanie gospodarek budujących socjalizm, o tyle podejście Schumpetera do możliwości rozwoju ustroju socjalistycznego było pozytywne. Obaj akceptowali kapitalizm, jednak Schumpeter dostrzegał w nim sporo wad. Zmarł w 1950 roku, przebywając od lat w Stanach Zjednoczonych, i nie mógł obserwować rozwoju socjalizmu w praktyce. Analizował więc czysto teoretyczny model. Można zadać sobie pytanie, czy gdyby Schumpeter żył dłużej i przyjrzał się gospodarce socjalistycznej, zmieniłby zdanie? Wydaje się, że nie. Nie był bowiem zwolennikiem tego ustroju, lecz chłodnym racjonalistą.

W życiorysie obu Austriaków można znaleźć wiele podobieństw. Obaj około pięćdziesiątki wyjechali do USA i przebywali tam kilkanaście lat (Hayek - 12, Schumpeter - 18). Obaj wiele uwagi poświęcili analizie gospodarki socjalistycznej. Obaj byli do niej krytycznie nastawieni. Jednak Hayek w pełni akceptował kapitalizm, Schumpeter natomiast dostrzegał jego ułomności oraz możliwość racjonalnego funkcjonowania państwa socjalistycznego.

\section{Literatura}

Gintis, H. (1990). Why Schumpeter got it Wrong in Capitalism: Socialism, and Democracy. Challenge Magazine, 34, 27-33.

Glapiński, A. (2004). Kapitalizm demokracja i kryzys państwa podatków. Wokót teorii Josepha Aloisa Schumpetera. Warszawa: Oficyna Wydawnicza SGH.

Godłów-Legiędź, J. (1992). Doktryna społeczno-ekonomiczna Friedricha von Hayeka. Warszawa: Wydawnictwo Naukowe PWN.

Hayek, F.A. (1940). Socialist Calculation: The Competitive 'Solution'. Economica, 7 (26), 125-149.

Hayek, F.A. (1945). The Use of Knowledge in Society. American Economic Review, 4 (35), 519-530. 
Hayek, F.A. (1949). The Intellectuals and Socialism. Pobrano z: https://mises.org/sites/default/files/Intellectuals\%20and\%20Socialism_4.pdf (20.08.2017).

Hayek, F.A. (1976). Socialism and Science. A lecture Delivered to The Economic Society of Australia and New Zealand on October 19. Pobrano z: http://westernciv.ipa.org.au/ library/publication/1213763502_document_review30-4_hayek_socialism_science.pdf (10.01.2018).

Hayek, F.A. (1977). Law, Legislation and Liberty. A Mirage of Social Justice. Vol. 2. Chicago: The University of Chicago Press.

Hayek, F.A. (1982). Two Pages of Fiction: The Impossibility of Socialist Calculation, Economic Affairs, 3 (2), 135-142.

Hayek, F.A. (1988). The Fatal Conceit: The Error of Socialism (the collected works of F.A. Hayek). London: Routledge.

Hayek, F.A. (1996). Droga do zniewolenia. Kraków: Wydawnictwo Arcana.

Hayek, F.A. (2006). Konstytucja wolności. Warszawa: Wydawnictwo Naukowe PWN.

Kostro, K. (2001). Hayek kontra socjalizm. Debata socjalistyczna a rozwój teorii spotecznoekonomicznych Friedricha Augusta von Hayeka. Warszawa: Wydawnictwo DiG.

McCaffrey, M. (2009). Can Capitalism Survive? Mises Institute. Pobrano z: https://mises. org/library/can-capitalism-survive (10.01.2018).

Schumpeter, J.A. (1995). Kapitalizm, socjalizm, demokracja. Warszawa: Wydawnictwo Naukowe PWN.

\title{
THE SOCIALIST STATE IN HAYEK'S AND SCHUMPETER'S VIEWS
}

\begin{abstract}
The article presents the position of two Austrian economists: Friedrich August von Hayek and Joseph Alois Schumpeter about the functioning of the socialist state. Both were supporters of the capitalist economy, but Hayek strongly denied the rationality of the socialist state. Schumpeter saw the disadvantages of capitalism, he saw the functioning possibility of a socialist economy using an economic calculation.
\end{abstract}

Keywords: Hayek, Schumpeter, socialism

JEL code: B12 